\title{
FINANCING CURRENT ASSETS DECISION IN WORKING CAPITAL MANAGEMENT: AN EVALUATION
}

\author{
Dr. G. Rajendran \\ Associate Professor, P.G. Department of Commerce, \\ Jawaharlal Nehru Govt. College, Port Blair, 744104, A\&N Islands, \\ Affiliated to Pondicherry University, A Central University, India
}

\begin{abstract}
The investment in current assets is imperative for the day-to-day operations of a business concern. It determines the liquidity and the profitability of the business concern. Financing current assets is a challenging task but this is one of the significant aspects of working capital management. It involves a crucial financial decision. There are various approaches available in determining an appropriate mix of financing current assets, but none of the approaches is completely satisfactory and acceptable. The present paper focuses on the real corporate world practices regarding financing current assets decision in working capital management. The main aim is to enlighten the shareholders, creditors, investors, bankers, prospective entrepreneurs, students and academicians relating to financing current assets decision and its implications. The study would reveal how far, the profit available and risk associated with the financing mix and a trade-off between risk and return will result in an acceptable financing strategy for most of business concerns.
\end{abstract}

Keywords: investment in current assets, Working Capital Management, Financing Current Assets.

Cite this Article: Dr. G. Rajendran, Financing Current Assets Decision in Working Capital Management: An Evaluation, International Journal of Management, 10 (2), 2019, pp. 39-46.

http://iaeme.com/Home/issue/IJM?Volume=10\&Issue=2

\section{INTRODUCTION}

The working capital management is concerned with the management of current assets. It is an integral part of the overall financial management. It is concerned with determination, maintenance, control, and monitoring of level of all individual current assets. The efficient management of working capital is important from the point of view of liquidity and profitability. Every firm must maintain a sound working capital position. It is an index of the solvency of the business. Poor working capital management, on the other hand, reduces liquidity and also reduces the ability to invest in productive assets, so affects the profitability since funds are unnecessarily tied up in idle assets. 
Fixed assets cannot work without working capital. Without it, fixed assets are like guns which cannot shoot as there are no cartridges. By maintaining adequate working capital, the concern enjoys and avails of so many benefits such as solvency, credit worthiness, and discount facilities due to prompt payment, expansions programmes, research and development. However, the excess working capital may result in unnecessary accumulation of inventories resulting in waste, damages and delays in collections of receivables due to more liberal credit terms. Inadequate working capital, on the other hand, may result in many consequences such as under utilisation of capacity, technical insolvency, unable to meet demand etc. So, a firm must have a well-defined working capital policy and a sound working capital management system to ensure higher profitability and adequate liquidity.

Financing of current assets has become the most crucial decision-making in the management of working capital. It refers to how current assets are financed i.e., the source from which it is financed. In other words, it is concerned with deciding the financing mix of working capital. It involves which component of working capital is financed by what source. Such a decision is taken in the light of risk and return associated with each source of finance. For the financial success of a firm, a trade-off between risk and return in choosing the most acceptable financing mix of working capital is essential.

\section{OBJECTIVES OF THE STUDY}

- To study the importance of financing working capital.

- To analyse the pattern of financing current assets of selected public limited companies.

\section{DATA BASE AND METHODOLOGY}

The present study is based on secondary data. The relevant secondary data was collected from annual reports of Hero Motorcorp Limited, Bajaj Auto Company Limited and TVS Motor Company Limited, books, journals, magazines and other documents. This is an analytical study of the financing pattern of current assets of Hero Motorcorp Limited, Bajaj Company Limited and TVS Motor Company Limited for the period of 10 years from 2008-2009 to 2017-2018.

\subsection{Tools for Analysis}

Ratio analysis has been used as a tool of evaluating the financing pattern of current assets of Hero Motorcorp Limited, Bajaj Auto Company Limited and TVS Motor Company Limited. Statistical tools such as averages, percentages have been used to quantify the data.

\subsection{Limitation of the study}

The present paper attempts to examine the perspective of financing pattern of current assets in the management of working capital of Hero Motorcorp Limited, Bajaj Auto Company Limited and TVS Motor Company Limited. All other aspects of working capital management of Hero Motorcorp Limited, Bajaj Auto Company Limited and TVS Company Limited have not been focused in this paper for the present study.

\subsection{Financing Current Assets Decision}

The most crucial decision-making in the management of working capital is financing of current assets. It is concerned with deciding the financing mix of working capital. It involves which component of working capital is financed by what source. There are two components of working capital namely permanent working capital and temporary working capital. The minimum level of current assets which must be maintained by any firm all the times in order to meet its business requirements is known as permanent working capital. The additional working capital needed over and above the permanent working capital to support the increased volumes 
of sales is known as temporary working capital. There are two main sources of financing working capital namely Long-term sources and short -term sources. Each source of finance has its own merits and demerits.

Financing of working capital from short-term sources has benefits low cost and establishing close relationship with the banks. But short-term source are more risky. Financing of working capital from long-term sources has the benefits of low risk and more liquidity since repayment of loans is not at frequent interval. But long-term sources are high cost. It will be appropriate to finance at least $2 / 3$ of the permanent working capital requirements from long-term sources. The variable working capita should be financed from short-term sources only for the period needed. There is no ideal set or combinations of these sources. There are three different approaches namely Hedging Approach, Conservative Approach and Aggressive Approach to take this decision relating to financing mix of the working capital.

The Hedging Approach involves matching the maturity of source of funds with the nature of assets to be financed. This approach is also known as 'Matching Approach' since the length of the finance should match with life duration of assets. According to this approach, the duration of working capital needs are classified into permanent working capital and temporary working capital. Permanent working capita refers to the constant portion of working capital needs of a business concern over a period of time. Temporary working capital refers to the additional working capital needs of a business concern in order to finance additional production and sales due to seasonal changes in demand. According to this approach, the permanent working capital needs should be financed from long term sources of funds and the temporary working capital requirements should be financed from short- term sources of funds. The Conservative Approach is a traditional approach under which all the working capital needs are primarily financed by long-term sources and use of short term sources should be restricted to unexpected and emergency situation only. The Aggressive Approach determines to finance a part of the permanent working capital and seasonal working capital by short term sources.

The hedging approach is a high profit (low cost)- high risk (No NWC) category while the conservative approach is a low profit(high cost) -low risk(high NWC) category. The hedging and the conservative approaches are both on two extremes. They do not help in efficient working capital management. A trade-off between these two can give satisfactory results.

The conservative approach is a low risk - low profit (high cost - high NWC) while the aggressive approach is a high risk- high profit (low cost - low NWC). A trade-off between these two extremes also can give acceptable financing strategy.

\subsection{Analysis of the Pattern of Financing Current Assets}

The pattern of financing current assets of f Hero Motorcorp Limited, Bajaj Auto Company Limited and TVS Company Limited has been analyzed with the help of analytical tools " 'the ratio of short-term funds to total funds and' the ratio of current assets to current liabilities' as below:

\subsection{Short-term Funds to Total Funds Ratio}

This ratio expresses the proportion of short-term funds to total funds. The main purpose of this ratio is to evaluate the method of financing policies by a firm. The ratio is computed as follows.

Short-term Funds to Total Funds Ratio $=\frac{\text { Short }- \text { term Funds }}{\text { Total Funds }}$

The lower the ratio, the less risky as well as less profitable will the firm but with more cost. The reason is that long-term funds are less risky but more cost. So, there will be a conservative financing policy which relies less on short-term funds and more on long-term funds. In contrast, the higher the ratio, the more risky as well as more profitable will be the firm with a low cost 
as short-term funds are more risk but less expensive than long-term funds. It indicates the presence of an aggressive financing policy which relies heavily on short-term funds and less on long-term funds.

\subsection{Current Assets to Current Liabilities}

Current Ratio is the most popular ratio among the ratios of liquidity. It is the ratio of current assets to current liabilities.

The main purpose of this ratio is to measure, the short-term solvency position of a firm ,the source from which the current assets have been financed and the risk and return involved in financing current assets.. The ratio is computed as below:

$$
\text { Current Ratio }=\underline{\text { Current Assets }}
$$

The standard for this ratio is 2:1. A high current ratio more than 2 times indicates that the company's liquidity position is sound and it has ability to pay its current obligations. The company uses the whole of short-term funds to finance current assets and a portion of longterm funds to finance current assets. It depends more on long-term funds to finance current assets. A low current ratio below 2 times, on the other hand, indicates that the company's liquidity position is not sound and it will find difficulty in paying its current liabilities. The company uses the whole of short-term funds to finance current assets and a portion of longterm funds to finance current assets. It relies less on long-term funds than short-term funds to finance current assets. However, a very high current ratio reduces the profitability of the concern since it depends more on long-term funds, for working capital which are costly. A very low current ratio below 1 indicates that the company bears even greater risk of insolvency in order to save cost of long term financing and thus in order to earn greater return.

Table-1 Exhibits the Short-term Funds to Total Funds Ratio and Current Assets to Current Liabilities Ratio of Hero Motorcorp Limited as below:

Table 1 Short-Term Funds to Total Funds Ratio and Current Assets to Current Liabilities Ratio of Hero Motorcorp Limited 2008-2009 To 2017-2018

\begin{tabular}{|c|c|c|c|c|c|}
\hline Year & $\begin{array}{c}\text { Short-term Funds } \\
\text { Rs in corer }\end{array}$ & $\begin{array}{c}\text { Total Funds } \\
\text { Rs in corer }\end{array}$ & $\begin{array}{c}\text { Current Assets } \\
\text { Rs in corer }\end{array}$ & $\begin{array}{c}\text { Short-term } \\
\text { Funds to Total } \\
\text { Funds Ratio(in } \\
\text { Percentage) }\end{array}$ & $\begin{array}{c}\text { Current } \\
\text { Assets to } \\
\text { Current } \\
\text { Liabilities } \\
\text { Ratio(in } \\
\text { times) }\end{array}$ \\
\hline $2008-2009$ & 2052.82 & 6085.14 & 1013.49 & 33.74 & 0.49 \\
\hline $2009-2010$ & 4831.41 & 8523.09 & 2882.58 & 56.69 & 0.60 \\
\hline $2010-2011$ & 6016.71 & 10726.26 & 5771.84 & 56.09 & 0.96 \\
\hline $2011-2012$ & 4341.44 & 9888.92 & 4830.96 & 43.90 & 1.11 \\
\hline $2012-2013$ & 4170.68 & 9641.65 & 5077.61 & 43.26 & 1.22 \\
\hline $2013-2014$ & 4423.00 & 10097.30 & 5555.88 & 43.80 & 1.26 \\
\hline $2014-2015$ & 3883.42 & 10521.70 & 5282.13 & 36.91 & 1.36 \\
\hline $2015-2016$ & 4048.82 & 12340.69 & 5935.09 & 32.81 & 1.47 \\
\hline $2016-2017$ & 4093.33 & 14694.26 & 7453.18 & 27.86 & 1.82 \\
\hline $2017-2918$ & 4343.32 & 16738.80 & 8848.18 & 25.95 & 2.04 \\
\hline$\times$ & & & - & 40.10 & 1.23 \\
\hline
\end{tabular}

$\bar{x}$ - Stands for Arithmetic Mean.

From the above Table -1 , it is clear that the ratio of short-term funds to total funds has been fluctuating between 43.90 percent and 25.95 percent except in the year 2009-2010, 2010-2011 with a mean figure of 40.10 percent. In the year 2009-2010, it was 56, 69 percent and in the year 2010-2011, it was 56.09 percent. It indicates that there is a low short-term funds to total 
funds ratio in most of the years. This means that the company has used an average of 40.10 percent to finance the total assets from short-term funds and an average of 59.90 percent to finance the total assets from long-term funds in most of the years. The financing mix of total assets, therefore, involves a high cost but a low risk.

The ratio of current assets to current liabilities has been fluctuating between 2.04 times and 1.11 times except in the year 2008-2009, 2009-2010 and 2010-2011with a mean figure of 1.23 times. In the year2008-2009, it was 0.49 times. In the year 2009-2010, it was 0.60 times and in the year 2010-2011, it was 0.96 times. The ratio has been much below 2 times in most of the years against the standard norm of 2:1. The company has used 0.49 times or 49 percent of the short-term funds to finance current assets and 0.51 times or 51 percent of the short-term funds to finance fixed assets in the year 2008-2009. It has used 0.60 times or 60 percent of the shortterm funds to finance current assets and 0.40 times or 40 percent of the short-term funds to finance fixed assets in the year 2009-2010. It has used 0.96 times or 96 percent of the shortterm funds to finance current assets and 0.04 times or 4 percent of the short-term funds to finance fixed assets in the year 2010-2011.

The company has used the whole short- term funds to finance current assets during the period 2011-2012 to 2017-2018. It has also used a part of long-term funds to finance current assets varying from 0.11 times or 11 percent to 1.04 times or 104 percent of current liabilities during the period 2011-2012 to 2017-2018. The company has followed neither conservative approach nor aggressive approach in financing current assets. The company has, therefore, followed the most acceptable financing mix of current assets policy and practice by a trade-off between risk and return. This financing mix of current assets may help in efficient working capital management of the company.

Table-2 Exhibits the Short-term Funds to Total Funds Ratio and Current Assets to Current Liabilities Ratio of Baja Company Limited as below:

Table 2 Short-Term Funds to Total Funds Ratio and Current Assets to Current Liabilities Ratio of Baja J Company Limited 2008-2009 to 2017-2018

\begin{tabular}{|c|c|c|c|c|c|}
\hline Year & $\begin{array}{c}\text { Short-term Funds } \\
\text { Rs in corer }\end{array}$ & $\begin{array}{c}\text { Total Funds } \\
\text { Rs in corer }\end{array}$ & $\begin{array}{c}\text { Current Assets } \\
\text { Rs in corer }\end{array}$ & $\begin{array}{c}\text { Short-term } \\
\text { Funds to Total } \\
\text { Funds Ratio(in } \\
\text { Percentage) }\end{array}$ & $\begin{array}{c}\text { Current Assets } \\
\text { to Current } \\
\text { Liabilities } \\
\text { Ratio(in times) }\end{array}$ \\
\hline $2008-2009$ & 2686.06 & 6042.42 & 2240.85 & 44.45 & 0.83 \\
\hline $2009-2010$ & 4287.95 & 8733.70 & 2921.63 & 49.10 & 0.68 \\
\hline $2010-2011$ & 3855.47 & 9247.53 & 3031.15 & 41.69 & 0.79 \\
\hline $2011-2012$ & 4625.16 & 11081.07 & 5190.15 & 41.74 & 1.12 \\
\hline $2012-2013$ & 4133.63 & 12478.62 & 6198.08 & 31.13 & 1.50 \\
\hline $2013-2014$ & 4730.24 & 14747.60 & 5616.63 & 32.07 & 1.19 \\
\hline $2014-2015$ & 4476.79 & 15562.32 & 9526.27 & 28.77 & 2.13 \\
\hline $2015-2016$ & 2780.99 & 16486.50 & 4725.25 & 16.87 & 1.70 \\
\hline $2016-2017$ & 3212.58 & 20814.89 & 9391.37 & 15.43 & 2.92 \\
\hline $2017-2918$ & 4111.29 & 23819.49 & 9235.63 & 17.26 & 2.25 \\
\hline $\bar{x}$ & & & & 31.85 & 1.51 \\
\hline
\end{tabular}

Source: Compiled and computed from the Annual Reports of Bajaj Company Limited.

$\bar{x}$ - Stands for Arithmetic Mean.

From the above Table -2 , it is clear that the ratio of short-term funds to total funds has been fluctuating between 41.74 percent and 15.43 percent except in the year 2008-2009, 20092010 with a mean figure of 31.85 percent. In the year 2008-2009, it was 44.45 percent and in the year 2009-2010, it was49.10 percent. It indicates that there is a low short-term funds to total 
funds ratio in most of the years. This means that the company has used an average of 31.85 percent to finance the total assets from short-term funds and an average of 68.15 percent to finance the total assets from long-term funds in most of the years. The financing mix of total assets, therefore, involves a high cost but a low risk.

The ratio of current assets to current liabilities has been fluctuating between 2.92 times and 1.12 times except in the year 2008-2009, 2009-2010 and 2010-2011with a mean figure of 1.51 times. In the year2008-2009, it was 0.83 times. In the year 2009-2010, it was 0.68 times and in the year 2010-2011, it was 0.79 times. The ratio has been much below 2 times in most of the years against the standard norm of 2:1 except in the year 2014-2015, 2016-2017and 2017-2018. The ratio has been much above 2 times in these years. The company has used 0.83 times or83 percent of the short-term funds to finance current assets and 0.17 times or 17 percent of the short-term funds to finance fixed assets in the year 2008-2009. it has used 0.68 times or 68 percent of the short-term funds to finance current assets and 0.32 times or 32 percent of the short-term funds to finance fixed assets in the year 2009-2010. It has used 0.79 times or 79 percent of the short-term funds to finance current assets and 0.21 times or 21 percent of the short-term funds to finance fixed assets in the year 2010-2011.

Table-3 Exhibits the Short-term Funds to Total Funds Ratio and Current Assets to Current Liabilities Ratio of TVS Auto Company Limited as below:

Table-3 Short-Term Funds to Total Funds Ratio and Current Assets to Current Liabilities Ratio of Tvs Company Limited 2008-2009 to 2017-2018

\begin{tabular}{|c|c|c|c|c|c|}
\hline Year & $\begin{array}{l}\text { Short-term Funds } \\
\text { Rs in corer }\end{array}$ & $\begin{array}{l}\text { Total Funds } \\
\text { Rs in corer }\end{array}$ & $\begin{array}{l}\text { Current Assets } \\
\text { Rs in corer }\end{array}$ & $\begin{array}{l}\text { Short-term } \\
\text { Funds to Total } \\
\text { Funds Ratio(in } \\
\text { Percentage) }\end{array}$ & $\begin{array}{l}\text { Current } \\
\text { Assets to } \\
\text { Current } \\
\text { Liabilities } \\
\text { Ratio(in } \\
\text { times) } \\
\end{array}$ \\
\hline 2008-2009 & 615.83 & 2560.68 & 893.67 & 24.05 & 1.45 \\
\hline $2010-2011$ & 1165.47 & 2857.51 & 1117.40 & 40.79 & 0.96 \\
\hline $2011-2012$ & 1345.18 & 3140.50 & 1078.30 & 42.83 & 0.80 \\
\hline $2012-2013$ & 1254.17 & 3119.27 & 1129.27 & 40.21 & 0.90 \\
\hline $2013-2014$ & 1529.16 & 3564.70 & 1408.72 & 42.90 & 0.92 \\
\hline $2014-2015$ & 2243.38 & 4604.20 & 2029.02 & 48.73 & 0.90 \\
\hline $\bar{x}$ & - & - & $\longrightarrow$ & 41.37 & 0.95 \\
\hline
\end{tabular}

Source: Compiled and computed from the Annual Reports of TVS Company Limited.

\section{$\bar{x}$ - Stands for Arithmetic Mean.}

The company has used the whole short- term funds to finance current assets during the period 2011-2012 to 2017-2018. It has also used a part of long-term funds to finance current assets varying from 0.12 times or 12 percent to 1.25 times or 125 percent of current liabilities during the period 2011-2012 to 2017-2018. The company has followed neither conservative approach nor aggressive approach in financing current assets. This reveals that the company depends more on long-term funds to finance current assets, during this period The company has, therefore, followed the most acceptable financing mix of current assets by a trade-off between risk and return only during the period 2011-2012 to 2015 -2016 because the ratio of current assets to current liabilities has been below 2 times. The ratio of current assets to current liabilities has been much more than 2 times during the period 2016-2017 to 2017-2018, which increases cost of borrowings more and erases the profits. 
From the above Table -3, it is clear that the ratio of short-term funds to total funds has been fluctuating between 48.73 percent and 24.05 percent except in the year 2017-2018 with a mean figure of 41.37 percent. In the year $2017-2018$, it was 52.64 percent. It indicates that there is a low short-term funds to total funds ratio in most of the years. This means that the company has used an average of 41.37 percent to finance the total assets from short-term funds and an average of 58.63 percent to finance the total assets from long-term funds in most of the years. The financing mix of total assets, therefore, involves a high cost but a low risk.

The ratio of current assets to current liabilities has been fluctuating between 0.96 times and0.68 times except in the year 2008-2009, 2009-2010 with a mean figure of 0.95 times. In the year2008-2009, it was1.45 times and in the year 2009-2010, it was1.32 times. The ratio has been much below 1 in most of the years against the standard norm of $2: 1$. The company has used the whole short-term funds to finance current assets during the period 2008-2009 to 20092010. It has also used a part of long-term funds to finance current assets varying from 0.45 times or 45 percent to 0.32 times or 32 percent of current liabilities during the period 20082009 to $2009-2010$.

The company has used short- term funds to finance the whole of current assets varying from 0.96 times or 96 percent to 0.68 times or 68 percent of current liabilities during the period 20102011 to 2017-2018. It has also used a part of short -term funds to finance fixed assets varying from 0.04 times or 4 percent to 0.32 times or 32 percent of current liabilities during the period 2010-2011 to 2017-2018. The company has followed an aggressive approach in financing current assets. This study reveals that the company depends more on short-term funds to finance current assets in most of the years. It also depends on short-term funds to finance a part of fixed assets. This increases risk as well as profits.

\section{FINDINGS AND SUGGESTIONS}

The Hero Motorcorp Limited has followed the most acceptable financing mix of current assets by a trade-off between risk and return. This financing mix of current assets may help in efficient management of working capital of the company. The company may maintain the ratio of current assets to current liabilities above 1 and below 2 times in order to compromise between risk and return. The Bajaj Auto company Limited has followed the most acceptable financing mix of current assets by a trade-off between risk and return only during the period 2011-2012 to 2015 -2016 because the ratio of current assets to current liabilities has been below 2 times in most of the years. The ratio of current assets to current liabilities has been much more than 2 times during the period 2016-2017 to 2017-2018, which increases cost of borrowings more and erases the profits. The company may reduce the excess investment in current assets so as to maintain the current ratio above 1 below 2 times in order to compromise between risk and return. This may help in efficient management of working capital of the company. The TVS Company Limited has followed an aggressive approach in financing current assets. This study reveals that the company depends more on short-term funds to finance current assets in most of the years. It also depends on short-term funds to finance a small portion of fixed assets in most of the years. The company has taken greater risk to save the cost of long- term financing current assets and thus to earn greater profits. The company may maintain the ratio of current assets to current liabilities above 1 and below 2 times in order to compromise between risk and return. This may help in efficient management of working capital of the company. 


\section{REFERENCES}

[1] Chandra P, Financial Management -Theory and Practices, Second Edition, Tata McGraw Hill Publishing Company Limited, New Delhi, 1989.

[2] Arpita Naskar and Prasanta Guha, Working Capital Management and Firm Profitability: A Study of Listed Companies in India. International Journal of Management, 8 (6), 2017, pp. 152-162

[3] Khan Y, Jain P.K, Financial Management, Third Edition, Tata McGraw Hill Publishing Company Limited, New Delhi, 2000

[4] Arunkumar O. N and T. Radharamanan, Working Capital Management and Profitability: An Empirical Analysis of Indian Manufacturing Firms, International Journal of Management (IJM), Volume 4, Issue 1, January- February 2013.

[5] Maheshwari S. N, Elements of Financial Management, Ninth Revised Edition, Sultan Chand \& Sons, New Delhi, 2005.

[6] Dr. E. Muthukumar and S. Sakeerthi. Working Capital Management Based on The Study at Sakthi Sugars, Tamilnadu. International Journal of Management, 7(2), 2016, pp. 536-547.

[7] Rustagi R.P, Financial Management, Galgotia Publishing Company, New Delhi, Second Revised Edition, 2000.

[8] Dr. Pavan Mishra, Dr. Soniya Rajpoot and Neeti Sharma. A study of Working Capital Management in Small scale. International Journal of Management, 7(2), 2016, pp. 266-278.

[9] Rajendran G, Financial Management - A Professional Approach (Text and Case Study), First Edition, Regal Publications, New Delhi, 2009.

[10] Rajendran G, Management Accounting (Text), First Edition, Regal Publications, New Delhi, 2009. 